when samples of these pure cultures were added to $1 \mathrm{ml}$. of sterile saliva and incubated overnight, they were found to remove most of the sialic acid, as measured by the method of Warren ${ }^{8}$.

It therefore seems that those organisms capable of growing on sterile saliva-agar are also capable of producing neuraminidase. This is confirmed by further subculturing with sterile liquid saliva when the specific loss of sialic acid can be easily assayed by chemical methods. The marked loss in reactivity of the incubated saliva to the periodic acid-Schiff reaction ${ }^{9}$ indicated that at least some of the other glycoprotein carbohydrates had also been lost, but at the present time this has been confirmed for fucose only. The most surprising aspect of this work from our point of view is that most of the oral bacteria, of which there are many different genera present ${ }^{10}$, seem to be able to produce neuraminidase and presumably the other complementary extracellular glycosidases when presented with an environment suitable for their elab. oration.

A more precise identification of the organisms involved and an attempt to produce a more easily available synthetic medium for demonstrating the presence of these enzymes is now being undertaken.

We thank the Medical Research Council and Unilever, Limited, for financial support.

S. A. Leach M. L. Hayes

School of Dental Surgery,

University of Liverpool.

Received September 12, 1967.

${ }^{1}$ Leach, \$. A., Nature, 199, 486 (1963).

${ }^{2}$ Middleton, J. D., Nature,202, 392 (1964).

Leach, S. A., and Critchley, P., Nature, 209, 506 (1964).

‘ Dawes, C., and Jenkins, f. N., Arch. Oral Biol., 7, 161 (1962).

- Gottschalk, A., Physiol. Rev., 37, 66 (1957).

- French, E. L., and Ada, G. L., J. Gen. Microbiol.,21, 550 (1959).

'Barker, S. A., Pardoe, G. I., and Stacey, M., Protides of the Biological Fluids, 11, 284 (1963).

- Warren, L., J. Biol. Chem., 234, 1972 (1959).

- Leach, S. A., and Hayes, M. L., Caries Res. (in the press).

1- Burnett, G. W., and Scherp, M. W., Oral Microbiology and Infectious Disease (Wiliams and Wilkins, Baltimore, 1957).

\section{DNA Base Composition of Toxoplasma gondii grown in vivo}

THe nature and taxonomy of the parasite Toxoplasma gondii are uncertain. A relationship to Besnoitia and Sarcocystis has been suggested ${ }^{1}$ and classification with Sporozoa has been proposed ${ }^{2,3}$. The problems have been discussed in detail ${ }^{4}$.

Phylogenetic relations of protozoa may be reflected in their DNA base compositions ${ }^{5}$, and information on DNA base composition may be particularly useful where relationships among Sporozoa are being examined because of their apparently polyphyletic origins ${ }^{4}$. This study was undertaken to provide such information for 'T'oxoplasma.

Toxoplasma ( $R H$ strain) were obtained from albino mice infected by the method of Blaker ${ }^{6}$. Dying animals were killed by spinal dislocation, and peritoneal exudates collected in heparinized buffered saline $(0.5 \mathrm{mg}$ of heparin [75 USP units] $/ \mathrm{ml}$. of $0 \cdot 1$ molar phosphate buffer, $p \mathrm{H} 7 \cdot 0$, made isotonic by the addition of $3.5 \mathrm{~g}$ of sodium chloride/1.). Cells were washed once in the same buffer, resuspended in saline-EDTA ${ }^{7}$ and leucocytes removed by filtration ${ }^{8}$ through a sintered glass filter (Corning, medium coarse

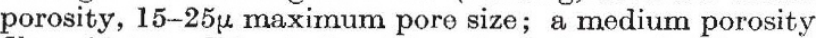
filter, $10-15 \mu$, did not allow T'oxoplasma to pass). The procedure also removes some Toxoplasma but has no effect on the viability of parasites as shown by mouse inoculation. Microscopic inspection of filtrates showed Toxoplasma and very few erythrocytes; leucocytes were rarely observed. Cells were lysed with sodium dodecyl sulphate and the DNA partially purified? ${ }^{7}$. The DNA base composition was determined by donsity gradient centrifugation ${ }^{9}$.

The DNA base compositions of organisms representing several subclasses of protozoa havo been reported and most cluster in groups which reflect their taxonomic position: Phytomastigophora ${ }^{5,10,11}$ range from 66 to 58 per cent guanine plus cytosine (Euglena, 46 per cent); Zoomastigophora ${ }^{5,12,13}, 59-50$ per cent; Holotricha ${ }^{5,10,14}$, 30̃-29 per cent (Tetrahymena patula, 22 per cent); and Rhizopoda ${ }^{5}, 22$ per cont.

DNA from Toxoplasma has a density of $1.712 \mathrm{~g} / \mathrm{cm}^{3}$ (Escherichia coli DNA taken as primary reference, $1.710 \mathrm{~g} / \mathrm{cm}^{3}$ ), and a guanine plus cytosine content of about 53 per cent. This value is close to that roported ${ }^{15}$ for the Haemosporidium, Anaplasma (about 50 per cent guanine plus cytosine), and also falls within the range of values reported for flagellates. A conclusive stater.ent on the position of Toxoplasma cannot be made, however, until additional data for the Sporozoa become available for comparison.

Harold NetMark ROBERT G. Blaker

Department of Microbiology and Immunology,

College of Medicine,

State University of New York,

Brooklyn, New York.

Received August 21; revised October 8, 1967.

Goldman, M., Carver, R. K., and Sulzer, A. J., J. Parasitol., 44, 161 (1958). ${ }^{2}$ Garnham, P. C. C., Baker, J. R., and Bird, R. G., Brit. Med. J., i, 83 (1962).

${ }^{3}$ Gavin, M. A., Wanko, T., and Jacobs, L., J. Protozool., 9, 222 (1962).

${ }^{4}$ Levine, N. D., .J. Protozool., 8, 442 (1961).

- Schildkraut, C. L., Mandel, M., Levisohn, S., Smith-Sonneborn, J. E., and Marmur, J., Nature, 196, 795 (1962).

${ }^{6}$ Blaker, R. G., J. Bacteriol., 82, 315 (1961).

7 Marmur, J., J. Mol. Biol., 8, 208 (1961).

${ }^{8}$ Fulton, J. D., and Spooner, D. F., Exp. Parasitol., 9, 293 (1960).

'Schildkraut, C., Marmur, J., and Doty, P., J. Mol. Biol., 4, 430 (1962).

Sueoko, N., J. Mol. Biol., 3, 31 (1961). Sucoko, N., Cold Spring Harbor Symp. Quant. Biol., 26, 35 (1961).

${ }^{11}$ Swartz, M. N., Trautner, T. A., and Kornberg, A., J. Biol. Chem., 237, 1961 (1962). 12 Marmur, J., Cahoon, M. E., Shimura, Y., and Vogel, H. J., Nature, 197,
1228 (1963).

${ }^{13}$ DuBuy, H. G., Mattern, C. F. T., and Riley, F. L., Srience, 147, 754 (1965).

${ }^{14}$ Smith-Sonneborn, J., Green, L., and Marmur, J., Nature, 197, 385 (1963).

${ }^{15}$ Kllender, R. D., and Dimopoullos, G. T., Proc. Soc. Exp. Biol. and Med. 125, 82 (1967).

\section{Uncoating and Development of Vaccinia Virus in Miniature Cells induced with an Extract from Marine Algae}

Dissection of individual cells by microsurgery into nucleate and anucleate cytoplasm provides an effective means for the delineation of nuclear participation during virus infection ${ }^{1}$. Recently, we described ${ }^{2}$ the formation of aberrant cells and mitotic anomalies after treatment of tissue cultures with a biologically active concentrate derived from marine algae. The induced abnormalities included mixed populations of micronucleate and miniature cells. The sequence of their formation was recorded by time-lapse, phase cinematography. Mieronucleation presumably occurred by a process similar to that obtained with colchicine ${ }^{3}$. Following metaphase, miniature cells were formed by multiple cytokinesis. Three to eight or more discrete daughter cells were usually produced from each mother cell thus affected. Each miniature cell con. 